\title{
EU Cohesion policy and the role of the regions: investigating the influence of Structural Funds in the new member states
}

\author{
John Bachtler, Irene McMaster \\ European Policies Research Centre, University of Strathclyde, 40 George Street, Glasgow G1 1QE, \\ Scotland; e-mail: john.bachtler@strath.ac.uk, irene.mcmaster@strath.ac.uk \\ Received 11 September 2006; in revised form 16 November 2006; published online 2 October 2007
}

\begin{abstract}
This paper undertakes a critical assessment of the influence of the EU Cohesion policy on regionalisation and the role of regional institutions in Central and Eastern Europe. It addresses questions that are central to ongoing theoretical debates about the role of the region in the new member states. Have the powers and resources of the regions been strengthened by their involvement in EU support programmes? Are regions increasingly involved in integrated 'bottom-up' responses to regional development challenges? The paper offers a fresh perspective on these issues, with a crossnational analysis of practical experience in the postenlargement period and a detailed assessment of the technical, variable, and complex reality of working with EU Structural Funds. A distinctive approach of the analysis is to disaggregate the stages of Structural Funds programme management and delivery, thereby highlighting the varied nature of regional involvement in Structural Funds. Ultimately, the paper questions the notion that Structural Funds build regional structures and competence, and lead to 'stronger regions'. Instead, it is argued that there is no guarantee that the Structural Funds will necessarily promote regionalisation in Central and Eastern Europe, at least in the short to medium terms.
\end{abstract}

\section{Introduction}

At the heart of institutional and governance debates on EU Cohesion policy is the argument that Structural Funds have increased the profile and influence of regional and local actors in economic development. As Benz and Eberlein (1999, page 335) note, since the landmark reforms of the Structural Funds in 1988, the Funds have been widely studied as a paradigm case of multilevel governance structures in the EU15 and of adjustment of regional structures (Börzel, 1999; Heinelt and Smith, 1996; Hooghe, 1996; Hooghe and Marks, 2001). Based on the preaccession and postaccession experience of the new member states, it has been suggested that EU Cohesion policy will similarly lead to changes in territorial relations within Central and Eastern European countries (Grabbe, 2003; Keating, 2003). Specifically, it is anticipated that Structural and Cohesion Funds will promote the greater involvement of regional-level institutions in economic development, with the potential for wider changes in regional governance structures and policy practice (Ferry, 2003a; Hooghe, 1996).

Recent policy developments would appear to support this thesis. In the run-up to EU accession, the Phare programme was used to provide direct support for subnational institutions in the new member states to assist them to prepare for Structural Funds. During the first Structural Funds programme period (2004-06) several accession countries implemented joint Regional Operational Programmes (ROPs), with the prospect of further decentralisation of programme management and delivery responsibilities in the $2007-13$ period. As under the regulatory reforms of 1988, 1993, and 1999, the 2006 European Council regulations governing EU Cohesion policy for 2007-13 emphasise the importance of involving regional and local authorities in the design and delivery of Structural Funds programmes (Council of the European Union, 2006). Indeed, the European Commission has argued that the Cohesion policy goal (of promoting growth, jobs, and competitiveness) in the 2007-13 period "will only work if it is owned by all stakeholders - at EU, national, regional and local levels" (Hübner, 2006, page 2). 
However, there is a need for caution in making judgments about the regionalisation of Structural Funds in the new member states of Central and Eastern Europe. ${ }^{(1)}$ The status of 'regions' varies greatly among the EU8 member states, reflecting country size, administrative structures, and political factors. These differences in territorial and institutional structures are associated with varying levels of subnational participation in the management and delivery of Structural Funds programmes.

A further analytical challenge is the Structural Funds implementation process. The allocation of EU Cohesion policy resources involves complex procedures of regional development planning, programme management and project delivery, with subnational bodies potentially having different roles and responsibilities in the decisions at each stage. As previously noted, the bureaucratic procedures have the potential to strengthen regional dependence on central government ministries (Slocock, 2003). Preliminary assessments of the experiences of the 2004-06 programmes in the EU8 have found considerable variation in the way that different aspects of Structural Funds implementation are being organised (McMaster and Bachtler, 2005).

Against this background, the aim of this paper is to undertake a critical assessment of the influence of EU Cohesion policy on regionalisation and the role of regional institutions in Central and Eastern Europe. It questions the assumption that Structural Funds will necessarily lead to 'stronger regions' by building regional structures and competence - at least in the short and medium terms - and that this is a particular 'benefit' of the Funds. In particular, the paper contends that, positioned between strong central government and well-established municipalities, region-level institutions may struggle to assert their role.

In order to establish the role of subnational institutions in EU Cohesion policy, this paper analyses in detail the implementation process through which Structural Funds are managed and delivered. It examines key stages of Structural Funds implementationregional development planning, programme management, programme implementation, and project implementation - with the aim of providing an in-depth and realistic assessment of regional involvement in Cohesion policy.

The paper draws on studies of strategy development and Cohesion policy implementation in eight new EU member states of Central and Eastern Europe: Czech Republic, Estonia, Hungary, Latvia, Lithuania, Poland, Slovak Republic, and Slovenia. The studies, led by the authors of this paper, involved extensive policy and literature reviews and elite interviews with national and regional-level organisations and actors in each of the EU8 countries, which were undertaken in 2003, 2004, and 2005. A team of researchers conducted semistructured interviews with senior representatives of key government ministries and agencies, regional and municipal authorities, and local interest groups.

The paper begins by reviewing debates surrounding the participation of regional administrations in Structural Fund programmes, and economic development more generally. It then outlines the key stages in Structural Funds development and implementation, and it assesses the planned, actual, and future inputs of regional institutions in the selected countries. By examining the various stages of Structural Funds implementation and practical experience across countries, we conclude that there is no guarantee that the Structural Funds will necessarily promote regionalisation or the role of regional authorities.

\section{Regionalism and Structural Funds in the EU8 member states}

The EU-and particularly EU Cohesion policy - is widely credited with exercising a strong influence on the evolution of regional-level structures and systems, as part of the

(1) In this paper the new member states of Central and Eastern Europe, which joined the EU in 2004-the Czech Republic, Estonia, Hungary, Latvia, Lithuania, Poland, Slovak Republic, Slovenia - are generally referred to as the 'EU8 member states'. 
design and implementation of regional development policies in the member states. Bache (1999), Börzel (1999), and Marks et al (1996a) suggest that the implementation of the Structural Funds has stimulated the creation of regional-level frameworks and institutions and has boosted regions' ability to steer economic development processes. Since the reform of the Structural Funds in 1988, EU Cohesion policy has involved a model of regional development based on: a concentration of resources on the poorest countries and regions; the allocation of funding through regionalised, strategic, multiannual programmes; the principle of subsidiarity, requiring decisions to be taken as close to the citizen as possible; and the principle of partnership, requiring the involvement of regional institutions and actors in negotiating development programmes and in implementing programmes and projects (Hooghe, 1996; Keating, 1995). Some authors have even suggested that the multilevel character of the EU has empowered subnational levels at the expense of the nation-state, which has had to accept a significant loss of control (Blom-Hansen, 2005; Marks et al, 1996b, page 346).

According to the governance literature, the influence of the Structural Funds has been twofold. First, it has contributed to a change in the structures of territorial administration (Coyle, 1997; Fabbrini and Brunazzo, 2003; Kleyn and Bekker, 1997; Svensson and Östhol, 2001). Based on the subsidiarity principle, Structural Funds management responsibilities have been devolved to lower levels of government (eg Italy, United Kingdom) or to deconcentrated offices of the state (eg France, Sweden) (Ferry, 2003a). Structural Funds are attributed with stimulating the development of new institutional frameworks at the regional level in Finland (Johansson, 1997) and Ireland.

A second influence of the Structural Funds, revealed by research on the partnership principle, relates to changes in the territorial relations between organisations and across levels of government. This concerns the way in which subnational authorities have become involved in the planning and implementation of Structural Funds programmes through various forms of consultation or cooperation, thereby increasing the profile and influence of the regional level (Kelleher et al, 1999), although with major differences between member states in the regional-level control of power and resources (Roberts, 2003). Structural Funds have been accorded a key role in mobilising and supporting regional development institutions and networks, which has helped them to lead and coordinate bottom-up, integrated responses to economic development challenges and, more generally, to establish a 'fabric' of regional organisations to support local businesses (Jones, 2001).

These developments are part of a broader trend discussed in the regional studies literature. Advocates of the 'new regionalism' argue that region-specific factors are fundamental to understanding contemporary patterns and processes of economic and social activity, and that region-level policies, institutions, and networks are important for developing and maintaining competitive advantage (Amin, 1999; Morgan, 1997; Storper, 1997; Storper and Scott, 1995). Related, and paralleling the reforms of the Structural Funds since 1988, regional development policies in many Western European countries have moved away from centrally administered aid schemes, targeted on designated assisted areas, towards regional-level programmes and strategies developed and implemented by regional bodies (either regional offices of the state or devolved institutions), as part of wide-ranging changes to the territorial governance of economic development (Bachtler, 2001; Halkier, 2006).

In the case of the EU8 member states, the influence of the EU on territorial structures and relations began with the 'conditionality' of EU membership obligations (Ferry, 2003b). These countries were obliged to meet the requirements of the acquis communautaire, the entire body of EU legislation. Chapter 21 of the acquis sets out detailed conditions and rules in the field of 'regional policy and the coordination of 
structural instruments', which stresses the importance of establishing an 'appropriate' form of territorial organisation for the implementation of Structural Funds and requires the adoption of the NUTS statistical classification system (European Commission, 2001). ${ }^{(2)}$ Further, the European Commission was felt to have a clear preference for the establishment of democratically elected, regional self-governments (Brusis, 1999; Marek and Baun, 2002; Yoder, 2003).

By controlling the negotiation process and issuing regular reports on progress towards meeting the accession criteria, the European Commission had a 'gate-keeping' role, exercising considerable influence over policy development and governance in all the applicant countries (Grabbe, 2003). Additionally, preaccession EU funding programmes, Phare, ISPA, and SAPARD, ${ }^{(3)}$ offered direct assistance to the accession countries, by providing financial resources and technical support for a range of activities, including institution building (Baun, 2002, page 267). These programmes had a key role in shaping new institutional frameworks for the development and delivery of EU funds, and territorial governance (Brusis, 2005). The European Commission (2005) credited EU programmes with supporting the development of good governance and strengthening the role of regions in countries such as the Czech Republic, Latvia, and Poland.

With previously limited or nonexistent regional policies, and weak regional economic development institutions, the accession countries faced a particular challenge in meeting the Chapter 21 criteria. Regional or provincial levels were generally weak, which left an 'administrative vacuum' between the powerful central government ministries and the numerous, small, and fragmented local government authorities (Bachtler et al, 2000). Territorial government reforms were often controversial, with bitter political conflict (Fowler, 2001; Illner, 2002). As the recent decision to delay regional administrative reform in Latvia indicates, some debates remain unresolved. However, the 'push' to fulfil the acquis was balanced by the 'pull' of the opportunities available from EU membership and participation in EU Cohesion policy programmes (McMaster, 2006). As a result, substantial regional and institutional reforms were undertaken in the lead-up to EU accession.

However, the degree to which the EU has exerted a powerful influence over regional institutional developments and regional 'empowerment', both in old and in new member states, has been challenged. Several authors argue that the influence of the EU, relative to the member states, has been exaggerated. Laffan (2004), for example, contends that national governments continue to be responsible for key decisions on territorial administrative reforms and regional institutional development. Specifically with respect to the implementation of EU Cohesion policy, Blom-Hansen (2005, page 648) goes so far as to state that "the EU ... appears impotent", while the member states "appear to be in full control". As the EU does not regulate the structure and status of regional institutions in the member states, domestic policy makers have considerable discretion in the way the Structural and Cohesion Funds are administered (Hughes et al, 2004; Marek and Baun, 2002a, 2002b). Experience demonstrates that institutional legacies and domestic policy preferences lead to variations in the response of domestic actors and institutions to regional development needs. In the case of regional participation in

(2) The Nomenclature of Territorial Units for Statistics (NUTS) was established by Eurostat to provide a single uniform breakdown of territorial units for the production of regional statistics for the EU. There are three main levels of regional unit, each with a minimum and maximum population size: NUTS I ( $3-7$ million); NUTS II ( $0.8-3$ million); and NUTS III $(150000-800000)$. NUTS II is used as the basis for determining regional eligibility for EU Cohesion policy support under the Objective 1/Convergence objective.

(3) In 2001 Phare had the largest financial allocation, worth approximately $€ 1.6$ billion at 2000 prices, followed by ISPA (Instrument for Structural Policies for Pre-Accession), with $€ 1.1$ billion, and SAPARD (Special Accession Programme for Agriculture and Rural Development) worth $€ 0.5$ billion. 
Structural Funds, some governments have chosen to allow greater regional involvement than others. Relevant responsibilities may be retained at national level (as in Portugal), deconcentrated to units of the state in the regions (as in England, Finland, France, and Sweden), devolved to regions (as in Italy), or operate through fully regionalised programmes under federal systems (as in Austria, Belgium, and Germany) (Ferry, 2003b).

More generally, the relevance of the 'new regionalist' approach has been questioned, particularly in Central and Eastern Europe. Linked to the Europeanisation literature, critics have argued that the role of the region has been overemphasised, while the role of the state and external factors in regional economic development are underestimated (eg Cumbers, 2000; Hudson, 1997; Lovering, 1999). Lovering (1999), for example, maintains that only those regions fortunate enough to find themselves in a favourable historical position will possess the cooperative networks and regional institutional capacity that, contribute to 'successful' economic development.

These arguments have a particular resonance in the EU8 member states for several reasons. Many regions are facing multiple, long-term economic development and restructuring challenges, with limited institutional and economic resources. The new regionalist approach assumes a political commitment, capacity, and resources at regional level, which may not exist. The EU8 countries have long-standing traditions of centralised, sectoral policy making, while regional institutional capacity is often weak. A further criticism of both the new regionalist and Europeanisation literatures, which has been much less widely explored, is that they take generalised perspectives in their analyses of the 'role' of the regions, especially in their assessments of Structural Funds programmes. The influence of EU Cohesion policy on regionalisation is frequently dealt with in a superficial way, with an assumption that an ideal 'regional' model of Structural Funds programming will eventually be replicated in the EU8.

In practice, the systems and structures involved in the development and delivery of EU funds are complex and variable, particularly in terms of the involvement of regions. First, there are several stages in the programming cycle where regions can be involved to a greater or lesser extent. Second, plans for regional involvement may be quite different to what actually happens in practice, as proposals on paper fail to be realised. Third, there is no single model for Structural Funds implementation. Fourth, regional programmes are only part of the Structural Funds story in the EU8, as resources are also allocated through sectorally oriented programmes and national funds.

Against the backdrop of these contested debates, the following sections of this paper examine the degree to which the implementation of EU Cohesion policy since 2004 has promoted regionalism in the EU8 member states. Taking account of the complexity and diversity of Structural Funds programmes, the paper addresses questions that are central to theoretical arguments about EU influence on the role of the regions. To what extent have the powers and resources of the regions been strengthened by their involvement in EU support programmes? Are regions increasingly involved in 'bottom-up' responses to regional development challenges? The paper offers a fresh perspective on these questions, with a cross-national analysis of practical experience in the postenlargement period and a detailed assessment of the technical, variable, and complex reality of working with EU Structural Funds. A distinctive approach of the analysis is to disaggregate the stages of Structural Funds programme management and delivery, thereby highlighting the varied nature of regional involvement in Structural Funds. Ultimately, the paper questions the notion that Structural Funds build regional structures and competence, and lead to 'stronger regions'. Instead, it is argued that there is no guarantee that the Structural Funds will necessarily promote the role of regional authorities or the cause of regionalisation in the EU8, at least in the short to medium terms. 


\section{Regional structures and Cohesion policy resources in the EU8 member states Regional administrative arrangements}

After the demise of state socialist regimes, the economic development policy priorities of postcommunist governments were to undertake fundamental macroeconomic, political, legal, and social reforms. Regional policy had a low priority, and there were few national or regional institutions or policies to address regional development problems. Specific measures for underdeveloped regions tended to be small scale and uncoordinated, as in the Czech Republic and Hungary. Regional administrative structures capable of delivering more regionally based, coordinated support programmes were generally lacking, and small scale, local/municipal governments were the main form of subnational administration. Due to their small size and limited revenue, many municipalities had problems functioning effectively and mobilising sufficient political, economic, and organisational resources to undertake meaningful development projects.

From the mid-1990s the negative impact of economic reforms - notably in heavily industrialised, agricultural, and peripheral regions - and EU accession requirements encouraged the accession countries to draw up regional development concepts and enact regional policy legislation (Bachtler et al, 2000; Blažek, 1999; Gorzelak, 1996; Smith, 1994). The institutional infrastructure for regional policy also began to be established, with the creation of regional development ministries or national agencies and interdepartmental committees. However, central government administrations were reluctant to decentralise powers and resources to regional levels of self-government; regionalised budgets or initiatives tended to be administered by regional offices of national ministries (Bachtler and Downes, 1999).

Since the late 1990s and early 2000s this situation has changed, with a growing awareness that the regional institutions for delivering regional development policies were inadequate. Several important steps have been taken to create frameworks for regional-level economic development, with some common elements.

- Deconcentrated units of the state. The most common form of regionalisation is the 'deconcentration' of central government responsibilities to regional offices of the state. Subnational offices of central government ministries operate in most countries to implement sectoral policy measures, with varying powers and resources, for example labour offices in the Czech Republic and Voivod offices in Poland.

- Regional development agencies. Among the first organisations to be established at the regional level with a specific regional policy remit were regional development agencies (eg the Czech Republic, Hungary, Poland, and Slovenia).

- Associations of municipalities. The local level has sought a greater role in shaping or administering regional policy through cooperative or collaborative associations of counties, districts, or municipalities, for example the Association of Estonian Cities, the Union of Local and Regional Governments of Latvia, the Association of Towns and Communities of Slovakia (ZMOS), the Union of Towns and Communities of the Czech Republic (SMOCR), and the Slovenian Association of Municipalities and Towns (ZRCALO).

- Planning regions. In complying with the EU requirements for creating territorial units under the NUTS system, planning regions have been created in some countries at NUTS II or III levels, for example in the Czech Republic, Hungary, and Slovakia. These planning regions have provided the basis for regional coordination mechanisms to enable the participation of lower administrative tiers in identifying regional development priorities.

- Self-governing regions. In a small number of countries-the Czech Republic, Poland, and the Slovak Republic-recent reforms have created self-governing regions which have facilitated greater levels of local/regional participation in the 
implementation of national regional policy and the development of their own regional strategies.

This diverse set of regional institutions and frameworks demonstrates that the scope for implementing EU Cohesion policy varies greatly. While the Polish NUTS II level (voivodship/regions) forms a rational basis for regional Structural Funds programmes, in the Czech Republic the NUTS II 'cohesion regions' combine two or three self-governing regions, and in Slovenia, Estonia, Latvia, and Lithuania, the country as a whole is a single NUTS II region (see table 1). Also, the financial, institutional, and human resources available to the regional level have (to date) been comparatively limited, even in those countries with self-governing regions (Blažek et al, 2003). Meanwhile, new institutions set up by central governments at the regional level (such as regional development agencies) have sometimes failed to establish credibility and trust among regional and local actors (Pálné Kovács, 2004). Indeed, Pálné Kovács et al (2004) have argued that "concepts such as regionalisation or partnership have been used as tools for the re-centralisation of the policy process and for resource distribution alongside clientele and clique interests" (page 457). This begs the question as to whether the regional-level bodies are 'regionally rooted', or whether they represent a pragmatic or artificial administrative response to the regulatory requirements of EU Cohesion policy.

Table 1. NUTS II regions and subnational authorities in the EU8 member states.

\begin{tabular}{lll}
\hline Country & NUTS II regions & Regional and local authorities \\
\hline Czech Republic & 8 & 14 regions \\
Estonia & 1 & 6249 municipalities \\
& & 15 counties \\
Hungary & 7 & 241 municipalities \\
& 1 & 3168 municipalities \\
Latvia & & 26 districts \\
& & 7 larger cities \\
& & 57 towns, 453 rural municipalities \\
& 19 & 10 counties \\
Lithuania & 16 & 60 municipalities \\
& & 16 regions \\
Poland & & 379 counties (including 65 city authorities) \\
& 4 & 2478 communes \\
Slovakia & & 50 districts \\
& & 2879 municipalities \\
Slovenia & 1 & 28 administrative units \\
& & 193 municipalities
\end{tabular}

\section{EU Cohesion policy programmes}

For the 2004-06 period, a financial allocation of $€ 24.5$ billion for Structural and Cohesion Funds in the period 2004-06 was agreed for the EU8 member states (see table 2). ${ }^{(4)}$ The EU8 agreed to implement most Structural Funds resources through central government, sectoral policy programmes. Notable exceptions were the Czech Republic, Hungary, and Poland, which had some form of joint or integrated ROP. In Slovakia the Operational Programme (OP) for Basic Infrastructure also incorporated a regional element. The resources allocated to these programmes were sometimes

(4) Out of forty-one NUTS II regions in the new member states, thirty-eight qualified for Objective 1 support. In the EU8 member states, only the regions of Prague and Bratislava had Objective 2 status. 
Table 2. EU Cohesion policy allocations for the EU8 member states 2004-06 (€billion) (source: European Commission, 2004).

\begin{tabular}{|c|c|c|c|c|c|c|c|}
\hline \multirow[t]{2}{*}{ Country } & \multicolumn{3}{|l|}{ Objective } & \multirow[t]{2}{*}{ Interreg } & \multirow[t]{2}{*}{ Equal } & \multirow{2}{*}{$\begin{array}{l}\text { Cohesion } \\
\text { Fund }\end{array}$} & \multirow[t]{2}{*}{ Total } \\
\hline & 1 & 2 & 3 & & & & \\
\hline Czech Republic & 1454.27 & 71.30 & 58.79 & 68.68 & 32.10 & 936.05 & 2621.19 \\
\hline Estonia & 371.36 & 0.00 & 0.00 & 10.60 & 4.07 & 309.03 & 695.06 \\
\hline Hungary & 1995.72 & 0.00 & 0.00 & 68.68 & 30.29 & 1112.67 & 3207.36 \\
\hline Latvia & 625.57 & 0.00 & 0.00 & 15.26 & 8.03 & 515.43 & 1164.29 \\
\hline Lithuania & 895.17 & 0.00 & 0.00 & 22.49 & 11.87 & 608.17 & 1537.70 \\
\hline Poland & 8275.81 & 0.00 & 0.00 & 221.36 & 133.93 & 4178.60 & 12809.70 \\
\hline Slovakia & 1041.04 & 37.17 & 44.94 & 41.47 & 22.27 & 570.50 & 1757.39 \\
\hline Slovenia & 237.51 & 0.00 & 0.00 & 23.65 & 6.44 & 188.71 & 456.31 \\
\hline Total & 14896.45 & 108.47 & 103.73 & 472.19 & 249.00 & 8419.16 & 24249.00 \\
\hline
\end{tabular}

considerable; the 2004-06 ROPs in the Czech Republic, Hungary, and Poland accounted for $31 \%, 18.6 \%$, and $40 \%$ of total national and EU funding, respectively. ${ }^{(5)}$ In the smaller countries regional development interventions generally made up one priority (or even just one measure) of the country's Community Support Framework (CSF) or Single Programming Document (SPD).

Notwithstanding commitments to the regionalisation of EU Cohesion policy programmes, the degree to which regions have an influence depends on the nature of their involvement at each stage in the process of drawing up national/regional development plans, the negotiation of OPs, and the management and delivery of interventions. As will be argued in the following sections, the roles of regional institutions in the various stages have hitherto varied greatly, raising questions about the levels of regionalisation and regional participation in Structural Funds programmes.

\section{National and subnational involvement in Structural Funds}

In theory, subnational participation in EU Cohesion policy programmes can involve several functions (see figure 1). At the programme planning stage, subnational levels may make an input to national programming documents through formal consultation. In some cases regional administrations may coordinate the development of individual OPs. Subnational bodies may participate in the management of 'regional' elements of programming documents or ROPs. Regional actors can take on key roles as implementing bodies. Lastly, subnational authorities have a potential role as project applicants and 'beneficiaries' of programme spending.

The following sections examine each of the main stages in the programming process in detail. The analysis focuses on developments in the 2004-06 programme period, and offers a timely opportunity to look back and reflect on developments. The analysis takes into account programming plans and guidelines, but since this only gives a partial view, practical experience with programme management and delivery in the EU8 is also assessed. ${ }^{(6)}$

(5) Author calculations based on figures available from Inforegio, Structural Funds: eligible areas in EU25 for Objective 1 and 2 between 2000 and 2006, http://europa.eu.int/comm/regional_policy/ atlas/index_en.htm

(6) Unless otherwise stated, the assessment of practical experience is based on fieldwork interviews with senior officials of ministries of economics, finance, or regional development in each of the EU8 member states, and a range of subnational authorities (particularly in the Czech Republic and Poland) carried out during 2003, 2004, and 2005. 


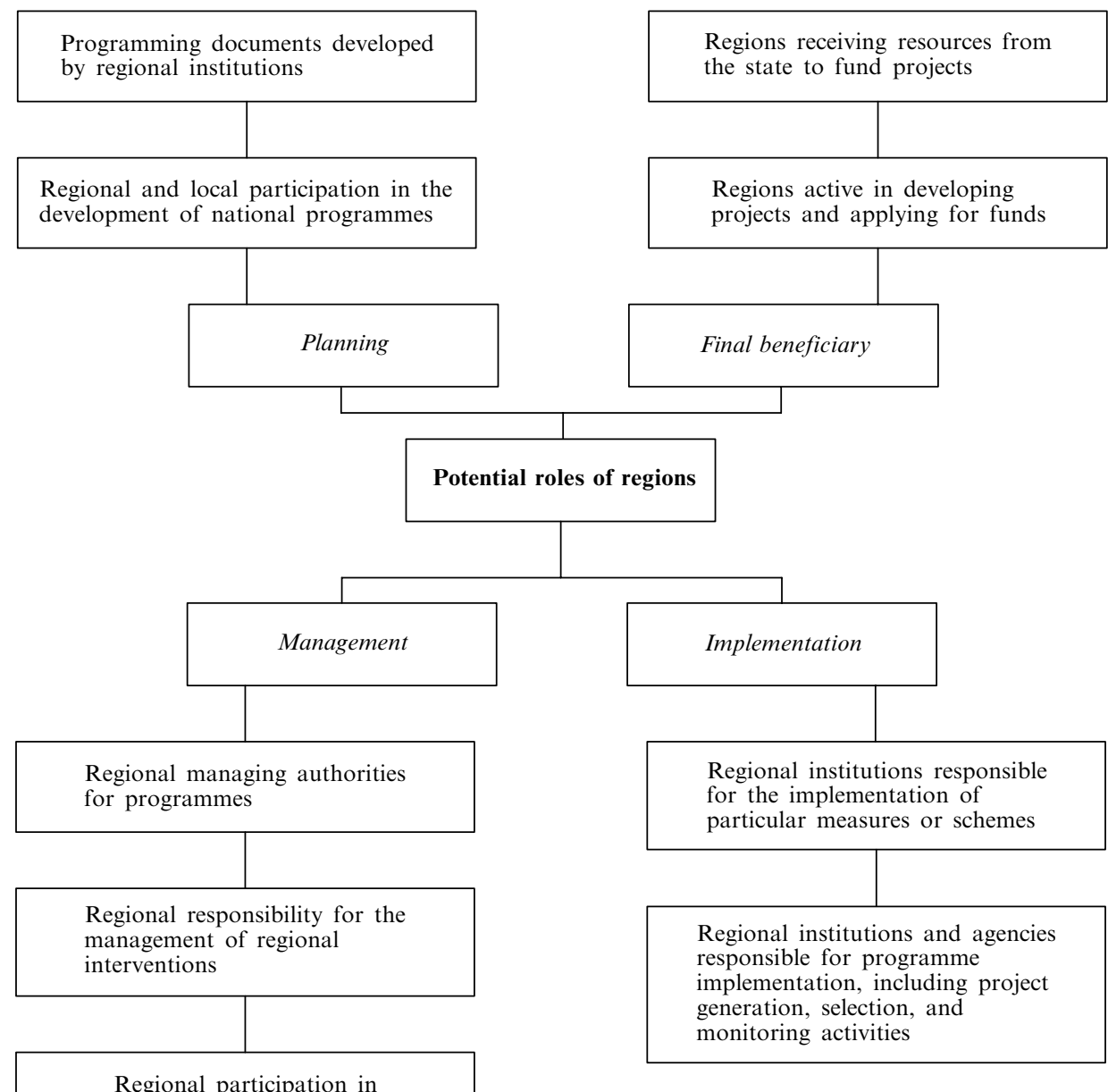

Figure 1. The potential roles of regions in Structural Funds programmes.

\section{Programme planning}

The starting point for developing Structural Funds programmes is the national/regional development planning stage. For the 2004-06 period this involved the EU8 member states drawing up national development plans (setting out how they planned to spend their allocations of EU Cohesion policy funding), conducting an independent ex ante evaluation of the plans, and submitting the plans to the European Commission for approval. Following negotiation with the Commission services - and in most cases amendment - the plans were approved as CSFs (for the Czech Republic, Hungary, Poland, and Slovakia) or SPDs (for Estonia, Latvia, Lithuania, and Slovenia).

At this stage in the process, regions can be involved in different ways. At a minimum they should be offered some formal consultation on member states' proposals. They may also be represented on planning groups and, in some cases, given responsibility for drafting regional planning or programme documents. Among some EU15 member states (particularly federal states) they may take the lead in the programming process and participate in the negotiations with the Commission services.

All EU8 member states made at least some attempts to involve subnational organisations in the planning processes for the 2004-06 programmes. At a minimum, 
national authorities made available draft copies of programming documents to subnational and nongovernmental organisations for comment. In Estonia the finance ministry invited comments on the basic strategy and, later on, the full SPD; a quarter of the partners responding to the second consultation were said to be municipalities and county governments, with the Ida-Viru county and the Union of Estonian Associations of Local Authorities described as being among the most "active" respondents (EMoF, 2003, page 17). Informal seminars were undertaken in each planning region of Latvia, although these were described as informational rather than consultative (LMoF, 2003). The most extensive regional participation in the programme planning process was evident in Poland, Hungary, the Czech Republic, and Slovakia, where individual ROPs were planned for the 2004-06 period and which-initially-gave regional administrations the scope to develop the structure and content of their 'own' programmes. In practice, however, the ROPs were abandoned in favour of joint or integrated ROPs, which, in theory, were meant to reflect the combined development agenda of all the regions.

These examples demonstrate that regions played a role in some aspects of programme planning, to varying degrees. However, the extent of regional influence on the major resource allocation decisions has to be seen in the context of traditionally centralised and sectorally oriented policy making and weak, newly established regional administrations or (in most countries) a lack of self-governing regions. In this context it is arguable that the influence of regions in practice was limited, and the obstacles to regional involvement were formidable, for several reasons.

First, the priority for national development programmes in the EU8 member states was (and is) to promote convergence in national income and employment with the rest of the EU. This was evident in the objectives specified for the 2004-06 Cohesion policy programmes which gave primacy to accelerating national economic growth by addressing major infrastructure deficits and promoting key economic sectors [for example, Habuda (2004) for Hungary, and Vilkas (2004) for Lithuania]. Regional development had a relatively small share of total EU funding, and much of its allocation was centrally determined, even in countries such as Poland which had regional programmes (Gorzelak, 2004).

Second, the process of allocating Cohesion policy resources involves difficult strategic choices about the priorities given to economic, social, and environmental goals, each of which is subject to strong political pressures and vested interests. Policy makers need to manage the high expectations of a range of societal and political groups in order to ensure the strategic coherence of Structural and Cohesion Funds programmes, with consistency in interventions and clear targets (Davies and Gross, 2005). Ultimately, it is central governments that need to arbitrate between competing interests in deciding the allocation of funding. As Bailey (2006, pages 25-26) notes, there is a tension between "balancing the need for political inclusion with the control/exclusion needed to uphold the authority of lead institutions and the efficient operation of the market economy" (pages 25-26). In this process regional authorities are just one of a range of different groups seeking to influence the development debate, a challenge which proved to be particularly difficult for regions lacking a directly elected regional self-government tier in the 2004-06 planning process (for example in Estonia, Latvia or Slovenia).

Third, the capacity of subnational structures to make an effective contribution to programme planning has been repeatedly questioned, particularly in the smaller member states (Bailey and De Propris, 2002; Kálmán, 2002). In Latvia and Slovenia, for instance, the lack of any regional level of self-government meant that subnational input was uncoordinated, fragmented, and localised. In Slovakia, regions were only just being 
established as the 2004-06 programming documents were developed; newly formed regional administrations (as in the Czech Republic) commonly lacked the technical capacity, human resources, and experience to offer high-quality input into the planning stage. In several countries the officials of coordinating government ministries claimed a lack of interest, coordination, cooperation, and strategic thinking on the part of regions.

Fourth, the commitment of government ministries to encouraging regional participation, and their own capacity to assimilate subnational input, was often weak. Interview research on the preparations for the 2004-06 period found that consultation was frequently perceived by subnational bodies to be formalistic and for information purposes only. The perceived lack of central government commitment to engaging in meaningful dialogue with the regions was attributed to the inexperience of government ministries in consultative policy making, and a lack of effective channels of communication/cooperation between levels of government. Consultations were also sometimes viewed as an obstacle to developing a coherent strategy, by adding more complexity to an already complicated process. As a result, little value was attached to the process, particularly where traditionally powerful ministries were reluctant to 'give up' control of the programming process.

Evidence from the ex ante evaluations of 2004-06 programming documents reinforces these findings. The Czech ex ante evaluation, for example, found that the programme planning process was affected by poor vertical cooperation mechanisms between national and regional levels (and also horizontally at each level) and a lack of effective communication between central government departments responsible for conceiving the policy or strategy and the implementing bodies at national and subnational levels (Blažek and Vozáb, 2006). Similar problems with national-regional cooperation were reported in the ex ante evaluation of Structural Funds planning documents in Poland (Bafoil, 2002).

Overall, it can be concluded that the involvement of regions in programme planning was at best mixed. Subnational authorities participated to a limited extent in consultations on the development of national programme plans, and a small number of regions were able to draw up their own regional strategy documents. However, the key decisions on programme development and resource allocation were taken by central government authorities, even under ROPs.

\section{Programme management and control}

The management of EU Cohesion policy programmes is complex. At the apex of the structure, during the 2004-06 period, member states were required to designate a 'managing authority' with overall responsibility for the assistance provided and for ensuring compliance with the Council Regulations (relating to the planning and management of programmes, monitoring of assistance, communication with beneficiaries, etc). They were also required to have: a 'paying authority', to manage payment flows between the Commission and beneficiary organisations; and a 'monitoring committee', comprising representatives of partner organisations, to oversee the implementation of the programme.

The assignment of managing and paying authority responsibilities to government departments was determined by the member states. During the 2004-06 period the overall responsibility for EU Cohesion policy was allocated to ministries of finance (Estonia, Latvia, Lithuania), ministries for regional development (Czech Republic, Poland, Slovak Republic), or government offices for regional/territorial development (Hungary, Slovenia). In the smaller countries (Estonia, Lithuania, and Latvia) most or all the managing authority functions were handled solely by the ministries of finance. In larger countries, with more EU funding, managing authority responsibilities were 
spread among different government departments. For example, in the Czech Republic, while the Ministry of Regional Development was the managing authority for the CSF as a whole, management of the individual OPs was undertaken by sectoral ministries. Similar arrangements applied in Hungary, Poland, and Slovakia. By comparison, the paying authority function was more restricted, being allocated to finance ministries in all member states; in some cases 'paying units' were established at OP level in other ministries to receive payment requests and pay out funding.

Under EU regulations, some of the managing authority powers could be delegated to so-called 'intermediate bodies', primarily to ensure effective financial management and control of expenditure. Most EU8 states took advantage of this provision, nominating the government bodies responsible for OPs or measures as intermediate bodies. As table 3 illustrates, these were either: central government ministries, particularly in the smaller countries; or state agencies, in the Czech Republic (eg CzechInvest, Czech Trade), Hungary (eg National Employment Office), Poland (eg State Committee for Scientific Research), and Slovakia (eg Slovak Energy Agency). In a few cases the intermediate body functions were undertaken by the regional offices of the state, notably the Voivod offices in Poland. In other cases, however, the regional involvement was limited to the part management of the regional development OP, for example, regional councils in the Czech Republic and marshal's offices in Poland.

Very little of the EU funding for the new member states was, therefore, managed or controlled at regional level. As previously noted, several EU8 member states originally had ambitious plans for regional management of 2004-06 OPs, as in Poland and the Czech Republic. In Poland the draft ROPs were produced by the regional marshal's offices and included analyses of the socioeconomic base of the region, a set of tailored priorities and activities to be undertaken, and a description of the process of consultation, monitoring, and financial arrangements (Ferry, 2003a). Related, new and existing offices made active preparations for their management role, and new, regionally based frameworks were planned to play a more active role in steering economic development on their own territory.

In practice, the Commission questioned the capacity of regional administrations to cope with programme management responsibilities, and relatively few functions were actually decentralised. Even programmes specifically targeting regional development had central government ministries as their managing authorities - as in the cases of the Ministry of Economy, Labour and Social Policy (Poland), Ministry for Regional Development (Czech Republic), Ministry of Construction and Regional Development (Slovakia), and the National Regional Development Office (Hungary). Despite opposition from the regional level (notably in Poland and the Czech Republic), plans for ROPs were abandoned in favour of centrally managed, joint, or integrated ROPs (ie multiregional programmes). In Poland, for example, the requirements of sixteen regions, each with different socioeconomic characteristics and separate strategic priorities, were integrated into a single ROP. Much of the potential regional value of the programming process - in terms of implementing measures and disbursing Structural Funds resources in line with regional priorities - was therefore considered to be diluted (Ferry and McMaster, 2003).

The main formal influence of subnational authorities on programme management was through their membership of monitoring committees. These committees comprised the managing and paying authorities, line ministries, intermediate bodies, implementing bodies (see below), economic and social partners, nongovernmental organisations and the European Commission (in an advisory capacity). As indicated in table 4, they also included some representatives of regional and local authorities. In Poland the regional state offices and the regional self-governments were represented on the CSF 
Table 3. Programme management and control responsibilities in the EU8 Structural Fund programmes, 2004-06. Source: authors' research from Community Support Frameworks (CSFs), Single Programming Documents (SPDs), and Operational Programmes (OPs) for 2004-06; and interview research.

Czech Republic

$\mathrm{CSF}$

Joint Regional OP

OP Industry and

enterprise

OP Human Resources

OP Infrastructure

OP Rural Development/

Agriculture

Objective 2 Prague

Objective 3 Prague

\section{Estonia}

\section{Hungary}

CSF

OP Regional Development

OP Economic Competitiveness

\section{OP Environment/ \\ Infrastructure \\ OP Human Resources}

OP Agricultural/Rural

Development
Ministry of Regional Development Ministry of Regional Development Ministry Industry and Trade

Ministry of Labour and Social Affairs Ministry of the Environment

Ministry of the Environment

Ministry of Regional Development Ministry of Labour and Social Affairs

Ministry of Finance

National Development Office

National Regional Development Office

Ministry of Economy and Transport

Ministry of Economy and Transport

Ministry of Employment and Labour

Ministry of Agriculture and Rural Development

Ministry of Finance
Centre for Regional Development and Regional Councils

CzechInvest; Czech Energy Agency; Czech Trade; Czech-Moravian Guarantee and Development Bank

Civic Society Development Foundation; Ministry for Education; Employment Agency Ministry of Transport; State Environmental Fund

State Agricultural Intervention Fund

Centre for Regional Development (regional branch); Regional Council (Prague) Employment Services Administration (MoLSA)

Prague City; Civic Society Development Foundation

Ministry of Social Affairs; Ministry of Economic Affairs and Communications; Ministry of Agriculture; Ministry of Finance; Ministry of Internal Affairs;

Ministry of Environment; Ministry of Education and Research

National Agency for Regional Development; Regional Development Agencies; Hungarian State Treasury

Regional Development Holding Group Company; Hungarian Development Bank; Hungarian Enterprise Promotion (PBC); Office for Research Fund Management and Exploitation; IT Information Society (PBC); Hungarian State Treasury

Ministry of Environment and Water; Energy Centre PBC; Hungarian State Treasury

National Employment Office; ESF National Implementing Agency; Ministry of Education; Ministry of Health, Social and Family Affairs; Hungarian State Treasury Agricultural and Rural Development Agency; Ministry of Regional Development and Local Governments (CFCU); Ministry of Welfare (State Employment Service); Ministry of Agriculture (Rural Support Service)

Ministry of Regional Development and Local Governments (CFCU); Ministry of Welfare (State Employment Service); Ministry of Agriculture (Rural Support Service) 


\section{Country}

Lithuania

Managing authority

Ministry of Finance

\section{Poland}

CSF

OP Economic

Competitiveness

OP Human Resources

OP Food Sector and Rural

Development

OP Fisheries and Fish

Processing

OP Transport-Maritime

Economy

Integrated Regional OP

\section{Slovakia}

CSF

OP Basic Infrastructure

\section{OP Human Resources}

OP Industry and Services

Energy

\section{OP Agriculture and Rural} Development

Objective 2 Bratislava

Objective 3 Bratislava

Slovenia
Ministry of Regional Development

Ministry of Regional Development

Ministry of Regional Development Ministry of Agriculture and Rural Development

Ministry of Agriculture and Rural

Development

Ministry of Infrastructure

Ministry of Regional Development (in cooperation with sixteen Voivodships)

Ministry of Construction and Regional Development

Ministry of Construction and Regional Development

Ministry of Labour, Social Affairs and Family

Ministry of Economy

Ministry of Agriculture

Ministry of Construction and Regional Development

Ministry of Labour, Social

Affairs and Family

Government Office for Structural

Policies and Regional Development
Intermediate bodies

Ministry of Economy; Ministry of Social Security and Labour; Ministry of Education and Science; Ministry of Agriculture; Ministry of Environment; Ministry of Transport and Communications; Ministry of Healthcare; Information Society Development Committee

State Committee for Scientific Research; Ministry of the Environment

Ministry of National Education and Sports

Agency for Reconstruction and Modernisation of Agriculture; Foundation for Assistance Programmes for Agriculture; Marshal's Offices

Agency for Reconstruction and Modernisation of Agriculture; Regional Sea

Fishery Inspectorate

General Directorate for National Roads and Motorways; Polish Railways

Voivod Offices

Ministry of Transport, Posts and Telecommunications; Ministry of Environment

Ministry of Education; National Labour Office

National Agency for SME (small and medium-sized enterprises) Development; Slovak Agency (and its regional branches); Slovak Investment and Trade Development Agency;

Slovak Tourism Agency

Agricultural Paying Agency

Ministry of Education

Ministry of the Economy; Ministry of Labour, Family and Social Affairs; Ministry of Agriculture, Forestry and Food 
Table 4. Programme implementation responsibilities in the EU8 Structural Fund programmes, 2004-06. Source: authors' research from Community Support Frameworks (CSFs), Single Programming Documents (SPDs), and Operational Programmes (OPs) for 2004-06; interview research.

\section{Country/Programme}

National implementing bodies

Czech Republic

Joint Regional OP

OP Industry and Enterprise

OP Human Resources

OP Infrastructure

OP Rural Development/Agriculture Objective 2 Prague

Objective 3 Prague

Estonia

\section{Hungary \\ CSF}

OP Regional Development

OP Economic Competitiveness

OP Environment/Infrastructure

OP Human Resources

OP Agriculture/Rural Development

Latvia
Centre for Regional Development; CzechInvest (measure 1.1);

Ministry of Regional Development (5.2)

CzechInvest (and regional offices); Czech Energy Agency;

Czech Trade; Czech-Moravian Guarantee and Development Bank

Ministry of Labour and Social Affairs; Ministry of Education,

Youth and Sports; Ministry of Regional Development; Ministry

of Industry and Trade; Ministry of Environment

Ministry of Agriculture

Centre for Regional Development (through regional branch)

Relevant agencies of Ministry of Social Affairs; Ministry of

Economic Affairs and Communications; Ministry of Agriculture;

Ministry of Finance; Ministry of Internal Affairs; Ministry of

Environment; Ministry of Education and Research (eg Foundation

of Life-long Learning, Enterprise Estonia, Agricultural Registers

and Information Board)

National Agency for Regional Development

Regional Development Holding Group Co;

Hungarian Development Bank; Hungarian Enterprise Promotion Public Benefit Company (PBC); Office for Research Fund Management and Exploitation; IT Information Society PBC

Ministry of Environment and Water; Energy Centre PBC

National Employment Office; ESF National Implementing Agency;

Ministry of Education; Ministry of Health, Social and Family Affairs Agricultural and Rural Development Agency

Ministry of Regional Development and Local Governments (CFCU);

Ministry of Welfare (State Employment Service); Ministry of

Agriculture (Rural Support Service)
Regional implementing bodies

Regional Councils (7)

Regional Offices of CzechInvest [some located in Regional Development Agencies]

Regions represented on project selection committees of the implementing bodies

Association of Regions of the CR represented on implementation Managing Committee and subcommittees for the OP. Kraj represented on NUTS III Regional Working Groups for the environment sector

which are responsible for project generation and preparation

Regional Division of State Intervention Fund

Regional Council (Prague Municipal Assembly)

Regional Council (Prague Municipal Assembly)

RDAs

Regional Development Councils appoint experts as members of the Project Selection Committee

Steering Committees for the four Funds include representatives of the Regional Development Agencies and Union of Local and Regional

Governments of Latvia 


\section{Country/Programme}

Lithuania

\section{Poland \\ CSF}

OP Economic Competitiveness

OP Human Resources

OP Food Sector and Rural

Development

OP Fisheries and Fish Processing

OP Transport-Maritime Economy

Integrated Regional OP

\section{Slovakia \\ CSF \\ OP Basic Infrastructure}

OP Human Resources

OP Industry and Services

OP Agriculture and Rural Development

Objective 2 Bratislava

Objective 3 Bratislava

Slovenia
National implementing bodies

Regional implementing bodies

Central Project Management Agency; Lithuanian Business Support

Agency; Transport Investment Directorate; Environment Implementing

Agency; Human Resource Development Programmes Support

Foundation; National Paying Agency

Polish Agency for Enterprise Development; Industrial Development Agency; Ministry of Scientific Research and Information Technology; National Fund for Environmental Protection and Water Management Ministry of Economy and Labour; Ministry of National Education and Sports; State Fund for Rehabilitation of Disabled Persons; Polish Agency for Enterprise Development; Civil Service Office Agency for Reconstruction and Modernisation of Agriculture;

Foundation for Assistance Programmes for Agriculture; Marshal's Offices Agency for Reconstruction and Modernisation of Agriculture supported by Fisheries Inspectorate Ministry of Transport $-$

Ministry of Transport, Posts and Telecommunications;

Ministry of Environment

Ministry of Labour, Social Affairs and Family;

Ministry of Education; National Labour Office

National Agency for SMEs (small and medium-sized enterprises)

Development; Slovak Energy Agency (and its regional branches); Slovak

Investment and Trade Development Agency; Slovak Tourism Agency

Agricultural Paying Agency

Ministry of Construction and Regional Development

Ministry of Education

Ministry of the Economy; Ministry of Labour, Family and

Social Affairs; Ministry of Agriculture, Forestry and Food
Regional Financing Institutions (some located in RDAs)

Voivodship labour offices

$-$

Implementation of the Integrated ROP (IROP) is divided between the Voivod Office and Marshal's Office (the latter being responsible for management of the regional component).

IROP regional component Steering Committee also includes representatives of: district and community self-governments; and socioeconomic partners from the area of the Voivodship.

Local infrastructure measures to be implemented in close association with regional self-governments

District Labour Offices

Note: Italics $=$ involvement in project preparation or selection. 
Monitoring Committee, while the Integrated ROP (IROP) also included representatives of district and community self-governments and socioeconomic partners from within the voivodships. Regions were also represented on monitoring committees in the Czech Republic (through the regional councils), Hungary (regional development councils), Slovakia (self-governing regions), and Latvia (regional development councils). Additionally, representatives of municipalities participated on the committees in some countries, generally through groups such as the Union of Local and Regional Governments of Latvia, the Hungarian Association of Cities of County Rank, and the Slovak Association of Towns and Municipalities.

While many of the monitoring committees had subnational representation, the influence of regions/municipalities should not be overstated. Although monitoring committees played an important, formal role in monitoring the implementation of the EU programmes, the size, breadth, and diversity of committee membership, the infrequent meetings (most met only two or three times a year), and the dense agenda meant that much of the committee work involved administrative 'rubber-stamping' rather than active management.

\section{Programme implementation}

Under EU rules, programme managing authorities can delegate administration of Structural Funds programmes to so-called 'implementing bodies'. These are organisations with responsibility for organising project selection, advising applicants, processing project applications, granting aid, receiving claims for payment, and monitoring project implementation.

Among the EU8 member states the implementation functions for the 2004-06 programmes were undertaken mainly by national government organisations, such as central government departments, development agencies, and sector organisations (see table 5). The main difference between countries is where the line was drawn between the management and implementation of programmes. For example, in the Czech Republic, several agencies - such as CzechInvest and the Czech-Moravian Development and Guarantee Bank - were entrusted with delegated responsibility both for aspects of management/control (as intermediate bodies) and also for implementation (as implementing bodies). By contrast, in Lithuania, government ministries retained all aspects of management/control, but delegated implementation to agencies (eg the Lithuanian Business Support Agency and the Environment Implementing Agency).

Subnational bodies were involved in programme implementation in most member states, but with big differences between countries. The most extensive regional involvement was under the IROP in Poland, where programme implementation was wholly regionalised. In each region, implementation was divided between the Voivod office (regional office of the state) and the marshal's office (regional self-government), with the latter being responsible for managing the 'regional component' of the IROP. In addition, the steering committees set up to oversee the administration of the IROP regional component included representatives of district and community self-governments and socioeconomic partners from the area of the voivodship. In the Czech Republic and Hungary the implementation of the ROPs was undertaken by national organisations - mainly the Centre for Regional Development for the Czech Joint ROP and the National Agency for Regional Development for the Hungarian ROP — but with region-level organisations also given a role as implementing bodies (regional development agencies in Hungary).

Among other programmes there was much more limited subnational involvement, and mainly through regional or local representation on implementation committees. For example, the steering committees for each of the four funds in Latvia included representatives of the regional development agencies and the Union of Local 
Table 5. Regional representation on Monitoring Committees in the EU8 Structural Fund programmes, 2004-06. Source: authors' research from Community Support Frameworks (CSFs), Single Programming Documents (SPDs), and Operational Programmes (OPs) for 2004-06; and interview research.

Regional representation

Czech Republic

$\mathrm{CSF}$

Joint Regional OP (ROP)

OP Industry and Enterprise

OP Human Resources

OP Infrastructure

OP Rural Development/Agriculture

Objective 2 Prague

Objective 3 Prague

Estonia

Hungary

CSF

OP Regional Developmen

OP Economic Competitivenes

OP Environment/Infrastructure

OP Human Resources

OP Agriculture/Rural Development

Latvia

Lithuania

Poland

Polan

OP Economic Competitiveness

OP Human Resources

OP Food Sector and Rural Development

OP Fisheries and Fish Processing

OP Transport-Maritime Economy

Integrated Regional OP

Slovakia

CSF

OP Basic Infrastructure

OP Human Resources

OP Industry and Services

OP Agriculture and Rural Development

Objective 2 Bratislava

Objective 3 Bratislava

Slovenia
Regional Councils

Regional Councils; Kraj (NUTS III); Regional Development Committees (monitoring subcommittees in the individual NUTS II regions)

Regional Councils

Regional Councils

"Delegated representative of regions"

Regional Council (Prague Municipal Assembly)

Regional Council (Prague Municipal Assembly)

"Representatives of regional authorities and local government unions"

"Representatives of the Regions"

Regional Development Councils

Regional Development Councils; Representatives of municipalities

Regional Development Councils; Representatives of municipalities

Regional Development Councils; Association of Cities of County Rank

Regional Development Councils

Regional Development Councils; Union of Local and Regional Governments of Latvia

"Regional/local partners"

Regional State Offices (Voivod Convents); Regional Self-Governments (Voivodship Marshal Convents)

Representative of Council of Marshals

Representative of Voivodship Convents and Council of Marshals

Representative of Voivodship Convents and Council of Marshals

One representative of local government

Voivods; Marshals; Representatives of: district and community self-governments; and socioeconomic partners from the area of the Voivodship.

"Representation of the Self-Governing Regions"

"Representation of regional and local levels"

"Where appropriate regional representatives may be involved in Monitoring Committee meetings"

Self-governing regions; Slovak Association of Towns and Municipalities

"Principal regional partners"

Bratislava Self-Governing Region; Municipal Council of Bratislava; Association of Towns and Communities of the Slovak Republic;

Union of Towns and Communities

"where appropriate ... regions which benefit from EU assistance provided ... might be invited to the Monitoring Committee meetings"

Subnational authorities represented by minister responsible for local authorities 
and Regional Governments. Regional self-governments in Slovakia also had some administrative responsibility for the local infrastructure measure under the Basic Infrastructure OP (participating in calls for proposals, selecting projects, and participating in monitoring and evaluation).

Notwithstanding such examples, the more general picture was one of state agencies controlling the implementation process, particularly in the member states that did not have regionally oriented programmes (eg Estonia, Latvia, Lithuania, and Slovenia). Even in countries with regional development programmes, much of the regional implementation was dominated by regional offices of ministries or state agencies, which has proved controversial. For instance, the Czech government's decision to establish regional offices of the Centre for Regional Development was viewed by some as "an attempt to establish another arm of the central state in the regions". (7)

This centralised approach to Structural Funds implementation reflected a concern - at EU and national levels - about the ability of government departments and agencies to cope with the regulatory, administrative, and technical demands of implementing programmes. Indeed, the experience of Structural Funds management in the 2004-06 period was characterised by numerous problems of institutional capacity. These related partly to what NEI (2002) has termed 'administrative absorption capacity', most notably inadequacies in the creation of appropriate institutional frameworks, building administrative skills, and ability within ministries and agencies, establishing the requisite primary and secondary legislation and developing administrative tools (such as manuals and guidance notes) and IT systems (Horvath and Maier, 2004). The responsiveness of the administrative culture is also regarded as critical. While Structural Funds management requires rapid and flexible responses to emerging needs, the experience of Hungary (like other EU8 countries) was that of an historically bureaucratic administration - an underdeveloped culture of accountability, risk-averse attitudes, and the lack of a 'customer oriented delivery network' (Kondor, 2004). Research on the intermediate bodies in Slovakia also found deficiencies in governance, management practices, financial resources, service delivery, and the quality of human resources (Barker, 2005).

A second problematic dimension concerned 'financial absorption capacity', relating to the ability of ministries and agencies "to co-finance EU-supported programmes, to plan and guarantee these national contributions in multi-annual budgets, and to collect these contributions from several partners (public and private) interested in a programme or project" (Horvath and Maier, 2004, page 7). The difficulties of absorbing (ie spending) Structural Funds resources were indicated by European Commission figures showing that while, by late 2005, the new member states had committed (awarded) $55-65 \%$ of their funds to projects, only $17 \%$ had actually been spent. ${ }^{(8)}$

It is important to note that the higher level doubts about administrative capacity were shared at regional level; some regions were concerned from the start about their ability to cope with programme management and implementation, owing to a lack of resources and their awareness of the complexities and demands of the responsibilities and tasks. ${ }^{(9)}$ Deficiencies in institutional capacity, ${ }^{(10)}$ lack of financial resources, and

(7) Author interview-Sdružení pro rozvoj Moravskoslezského kraje (Union for the Development of the Moravia-Silesia Region), Ostrava, March 2003 and Agentura pro regionální Rozvoje Ostrava, March 2003.

(8) Figures from DG REGIO, European Commission, 18 November 2005.

(9) Author interview, Prague, 2003.

(10) The labour-intensive nature of Structural Funds administration can be illustrated by the number of staff involved in administering the five Czech OPs: the managing authorities and intermediate bodies employed 701 staff in 2004 (European Commission, 2006). This figure would increase substantially if the paying authority staff (and paying units), and all the staff involved in implementing bodies and financial beneficiary organisations, were to be included. 
weak coordination among regional organisations were perceived as severe limitations (Grosse, 2004). In the Czech Republic, Poland, and Slovakia, inadequate resources constrained the ability of self-governing regions to fund development initiatives. Polish regional self-governments found it difficult to hire new personnel due to budget limitations, and they also suffered from the politicisation (rather than professionalisation) of staff; a change of administration after elections was frequently followed by a major turnover of staff. In all of the EU8 member states low public sector pay contributed to high levels of staff turnover at every level of government.

In summary, therefore, the involvement of the regional level in the administration of Structural Funds programmes was extremely weak during the 2004-06 period. In the Czech Republic, Hungary, and Poland, subnational authorities did exercise some control over some EU-funded interventions. However, these activities only made up a small part of programme funding in each country. Government ministries and state agencies dominated this aspect of the programme cycle, particularly in Estonia, Lithuania, Latvia, and Slovenia. Additionally, the implementation of sectoral operation programmes involved very little input from regional administrations. A lack of resources and limited experience of some regional institutions were constraints on the regional level playing a greater role.

\section{Project implementation}

The final level of Structural Funds administration is the individual 'project' or 'action' where the priorities and measures of EU programmes are put into practice. Applicant organisations put forward proposals for funding to the implementing bodies; these may be applications for individual projects (for example, the construction of new infrastructure or a technology centre) or for actions such as grant schemes to support SMEs or individuals. It is at this stage that the role of subnational institutions and actors is strongest, as they have a key role in submitting project applications in order to benefit from the Funds. Many programme priorities and measures list regions and subnational administrations as their 'final beneficiaries'. (11)

The experience of the EU8 in the 2004-06 period was that, despite early concerns of low take-up, the application rates from subnational organisations was high. The European Commission's first comprehensive assessment was that: "initial experiences indicate that the interest of beneficiaries has exceeded expectations" (European Commission, 2006). By the end of 2004 commitment levels were in the range $24-53 \%$; these figures increased to $55-65 \%$ by the end of 2005 and were close to $100 \%$ in most countries by mid-2006. ${ }^{(12)}$

In the lead-up to accession, national governments and the European Commission undertook a range of actions to support and generate projects, many of which were targeted at the subnational level. For instance, in the Czech Republic, the so-called Absorption Capacity (ABCAP) project was undertaken in 2003-04 to help the owners/guarantors of projects to prepare project applications. In total, 770 successful projects and schemes were assisted (ECR, 2004). In Hungary preparatory project support activities included an information centre (providing generic information) and a training centre (providing training for organisations involved in Structural Funds management and implementation). Regionally based specialist consultancy companies also played a part in helping potential beneficiaries to develop their project

(11) A 'final beneficiary' is a public body, private firm, or social group which is allocated EU programme support to carry out a project or action. In the case of aid schemes, the final beneficiaries are the bodies which grant the aid to firms etc (which are the ultimate recipients).

(12) Figures provided by DG REGIO, European Commission. However, as noted earlier, the performance on commitments was not matched with respect to payments, which were very slow at first. 
submissions (eg in the Czech Republic and Estonia), although their services could be costly, of variable quality, and with limited accessibility. For example, in Estonia, advisory centres tended to be concentrated in areas where project submission rates were already high, around Tallinn and Tartu.

However, high application rates and strong regional involvement were not universal. The number and quality of applications differed considerably between regions. For example, in Latvia, relatively few project applications were received for projects in Latgale, the poorest region in the EU. In Estonia stronger municipalities were found to be more likely to have the financial and human resources to develop better project proposals. In other cases, some 'lagging' regions, with long-standing experience of EU support through preaccession aid, appeared to be well placed for developing more innovative and robust project submissions, for example, Moravia-Silesia region in the Czech Republic, or Silesia in Poland.

More generally, region-level bodies made far fewer applications than local organisations. Figure 2 illustrates the different levels of participation between regional and local levels in Structural Funds project proposals in the Moravia-Silesia region. A similar pattern was apparent in other Czech regions, in Poland (Ochojski, 2003), and in Hungary. ${ }^{(13)}$ In the smaller member states the 'administrative gap' at regional level meant that municipalities had an even greater role to play in drawing down EU funds by submitting project applications.

A major obstacle to regional involvement was a lack of financial resources at regional level for cofinancing EU-funded projects. In Poland it has been argued that the capacity of regional governments to fund projects was constrained by insufficient funding from central government, combined with inadequate tax-raising powers to generate their own resources (Ferry, 2007). In Hungary, particular concerns were expressed about the capacity of economically weak regions to cofinance projects. In the Czech Republic, self-governing regions depended on funding allocated to them by central government. In fact, the pressure that cofinancing placed on regional budgets could actually limit the capacity of regional administrations to initiate autonomous or independent interventions, as their spending programmes would be tied to Structural Funds programmes.

In contrast, municipalities and cities were generally better resourced to provide cofinancing for small-scale, local regeneration projects (Ferry and McMaster, 2005).

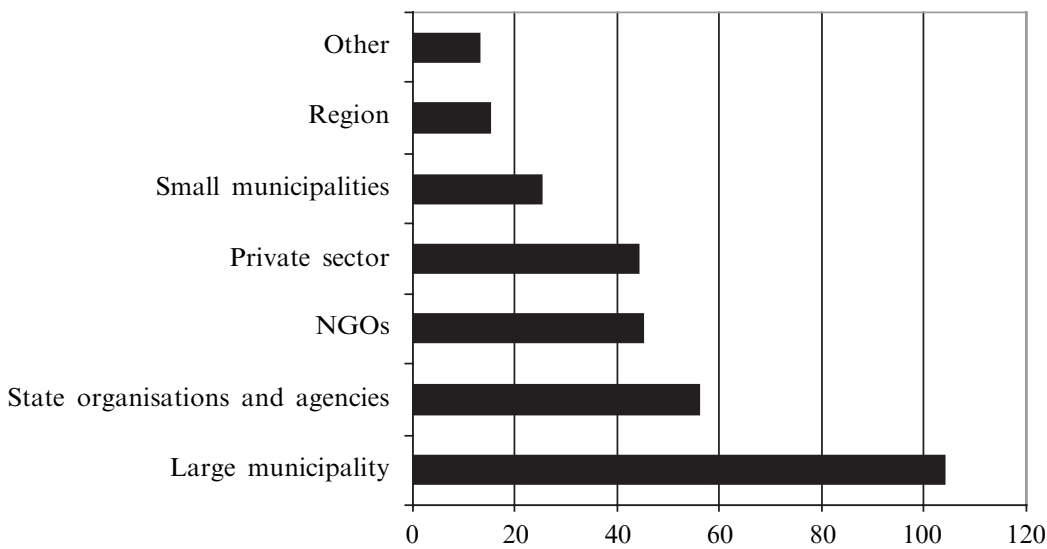

Figure 2. Structural Funds project proposals in the Moravia-Silesia region (source: ECORYS, 2003).

(13) Author interview, National Regional Development Office, Budapest, April 2006. 
For instance, in Poland and the Czech Republic the fiscal powers of municipalities meant that they could raise and disburse funds, putting them in a stronger financial position in terms of cofinancing initiatives. ${ }^{(14)}$ However, the small size of municipalities meant that projects suffered from fragmentation, restricted scope/imagination, and, at times, limited viability. Additionally, linked to constraints on capacity and resources, large numbers of projects tended to focus on physical investment in 'tried and tested' areas of activity, possibly at the expense of 'softer' or more 'innovative' measures.

In summary, it is as project developers and final recipients of Structural Funds that subnational authorities played their most important roles. However, lack of capacity and resources meant that regional administrations tended to play a less active role than municipal authorities, which tend to be longer standing institutions and better resourced.

\section{Regionalisation in 2007-13}

As a new generation of programmes for the 2007-13 period is launched, the role of regional administrations in the management and implementation of Structural Funds could change. The basic principles of EU Cohesion policy have been retained in the new Council regulations (Council of the European Union, 2006), but with a stronger obligation on member states to ensure that the design and implementation of Structural Funds programmes is undertaken in partnership with subnational authorities. How this is interpreted in practice in the EU8 member states will become clear over the next seven years, although some initial insights are provided by the National Strategic Reference Frameworks (NSRFs) drawn up by each member state as a basis for Cohesion policy spending in the $2007-13$ period.

The NSRFs and OPs indicate a considerable regionalisation of EU funding in the four larger EU8 member states (Poland, Hungary, Czech Republic, Slovakia). Under the 2007-13 programmes preferential support is being provided for weaker or lagging regions, through the financial allocations made to regions (Poland), through 'reserved resources' in each of the OPs (Czech Republic), or through project selection criteria at priority level (Slovakia). Also, the use of multiregional operational programmes is being replaced by region-specific programmes: sixteen for each of the voivodships in Poland; seven in Hungary; eight in the Czech Republic; and eight in Slovakia.

The implications for governance are most significant in Poland where the role of managing authority for the ROPs is passing from the Ministry of Regional Development to the self-governing regions and their executive bodies, the marshal's offices, although crucial paying authority and certification functions will be retained by central government and the regional offices of the state. Similarly, in the Czech Republic and Hungary the regional councils will take on managing authority responsibility for the ROPs. Some of the smaller countries, for example, Slovenia and Latvia, are also taking steps to engage subnational authorities in the delivery of the 2007-13 programmes, albeit more with respect to implementation than management.

The devolution of management of responsibility for the ROPs is an important step towards giving regions greater control of EU Cohesion policy, with potential implications for further decentralisation of economic development in the future. However, there are some important caveats. First, the regionalised programmes represent only a part of the overall EU Cohesion policy funding. Whereas the Polish regions will manage some $29 \%$ of the Structural and Cohesion Funds, in Hungary the ROPs will account for $24 \%$, and in the Czech Republic only $13 \%$. 
Second, the 'parallel structures' of regionalised ROP management and centralised control of payments are a source of central-regional tensions. In Poland central government is seeking to impose consistency of implementation across all regions (for example with respect to project selection procedures), while the regions advocate implementation arrangements to suit regional circumstances.

Third, the limited resources of regional self-governments constrain their ability to undertake their own regional development projects with EU funds and make them reliant on funding from other sources (municipalities, regional offices of the state, NGOs, etc). The management responsibilities also present organisational and personnel challenges, most notably coordination across departments and the recruitment of sufficiently qualified staff.

Fourth, regionalisation is associated with more complex administration. In some of the larger member states the OPs had thirty to forty implementing bodies in the 2004-06 period (Šumpíková et al, 2004); the administrative arrangements for the Czech and Polish joint ROPs were criticised in evaluation reports as being particularly complex (McMaster and Bachtler, 2004). The creation of ROPs for the 2007-13 programmes is adding an additional 'regional layer' of implementation, as the regions establish their own implementing bodies.

Lastly, regions may find it difficult to achieve some of the strategic objectives of their ROPs. The experience of the 2004-06 period was that implementing bodies were ill prepared for the task of actively promoting economic and social development (McClements and Smolkova, 2004). It was not uncommon for implementing agencies to uphold 'traditional' or 'compartmentalised' approaches, by limiting themselves to purely administrative activities or well-established areas of activity. Given the concerns about the capacity and relative inexperience of regional institutions, their ability to take on a more strategic role could be limited. At the same time, taking responsibilities away from existing agencies reduces the scope to build on past experience.

\section{Conclusions}

In this paper we set out to examine the assumption that EU Structural Funds lead to 'stronger regions' EU8 member states, by building regional structures and competence, and also the assumption that this is a particular 'strength' of the funds. Parts of the contemporary literature have suggested that the actual or potential influence of EU Structural Funds on regional governance structures and policy practice is particularly pronounced in the EU8 member states, with the result that regions (will) have an important role to play in the development and delivery of Structural Funds programmes. These arguments are situated within the new regionalism debates on the importance of regional and local actors engaging with, and advancing, economic development agendas, and the influence of the EU on regional institutional development.

The scope for Structural Funds to develop the role of regions and encourage bottom-up, regional involvement in promoting economic development is based on several factors, linked to legitimacy, institution building, and capacity development. This paper's analysis of the practical experience of managing and implementing Structural Funds in 2004-06, and plans for the 2007-13 period, as opposed to developments in the preaccession period, identifies several points to support the contention that the role of regions has increased in terms of their legitimacy, institutional stability, and capacity (see table 6).

In the past, regional involvement in economic development policies was extremely limited, as programmes were largely centrally controlled and sectorally oriented. By contrast, at the planning stage for EU programmes, specific provisions were made: to involve regions either in the development of national development programmes or in 
Table 6. Roles of central and subnational levels in the EU8 2004-06 Structural Funds programmes.

Structural Funds programme functions

Planning

Management

Programme implementation
Roles of central and subnational levels

central government

subnational authorities
Strong: ministries largely responsible for programme development, including coordination of joint Regional Operation Programmes (ROPs)

Strong: ministries and agencies fulfilled Managing Authority and Intermediate Body functions

Strong: ministries and agencies had lead role as implementing bodies

Mixed: ministries and agencies

Project

implementation were are generally responsible only

for implementing large

infrastructure projects.
Mixed: some regional and local consultative input. Regional strategies sometimes formed the basis for joint ROPs

Weak: very limited management role, mainly through representation on Monitoring Committees

Mixed: some implementation through regional offices of ministries and agencies. Regional and local bodies responsible for some joint ROP priorities or measures or represented on project selection committees.

Strong/mixed: local authorities were very active in implementing projects as final beneficiaries.

Regional authority participation was more variable.

programmes specifically targeting regional development concerns; and to increase the legitimacy of the programmes through partnership working. The Czech Republic, Hungary, and Poland have encouraged regional institutions to build their own capacity and take charge of developing - and subsequently managing - new regional programmes for the 2007-13 programming period. An increasingly stable framework of regional institutions, including regional development agencies, regional self-governments, and specially formed regional councils, are responsible for the regional implementation of some components of Structural Funds programmes, by generating, selecting, and monitoring projects. Lastly, as final beneficiaries of the funds, regional institutions play a critical role, since it is by drawing down resources and undertaking projects that Structural Funds have the greatest impact on the ground. It is at this stage that the input of subnational institutions is particularly strong.

This evidence appears to reinforce the contention that EU Structural Funds support regional institutions, strengthening their previously weak position in the development and delivery of regional policy. Their participation first in Phare accession projects and now in Structural Funds programmes is encouraging a more 'bottom-up', regionally based approach to intervention. The combination of greater capacity, resources, and experience gives the regions the opportunity to establish themselves as important actors in the field of regional development, not least through the tendency of regions to compete with each other to secure economic and institutional advantage. ${ }^{(15)}$

However, as this paper's analysis has also illustrated, the limitations and barriers to regional participation in the funds currently outweigh the opportunities. In fact, it is possible to question whether Structural Funds have led to 'stronger regions',

(15) The authors are grateful to an anonymous referee for making this point. 
by contributing to the development of legitimacy, institutional framework, and capacity at regional level.

The relative novelty of regional administrations in many EU8 member states, and their limited experience of Structural Funds, mean that there has been a little time for member states and regions to adapt and take on new responsibilities. Organisational arrangements will change in the future, as regional institutional frameworks stabilise and their experience grows. However, it is also possible to highlight a number of 'barriers' to regional participation that are firmly rooted in distinctive national policy approaches and strategic decisions involved in the management and implementation of Structural Funds.

First, as previous studies have highlighted, the role of regions in Structural Funds programmes has to be set against a context of the limited influence of the EU in some policy areas, relative to national governments. As Laffan (2004) and Blom-Hansen (2005) note, EU legislation does not compel the member states to decentralise decisions to regions and municipalities. In practice, the degree of subnational involvement depends on constitutional arrangements, the institutional structures of individual countries, and the size of the country.

As discussed above, not all of the EU8 member states have regional institutional structures that are capable of participating in Structural Funds programmes. Questions can be raised about the capacity of regional institutions to deal with the scale and type of issues that the EU8 regions are facing. Where dedicated institutional frameworks have been set up in connection with Structural Funds one can ask how 'regionally rooted' these institutions are, and how effective they are likely to be. Are they 'real' regionally based institutions, or pragmatic responses to the administrative demands of Structural Funds? The evidence presented in this paper suggests that the latter applies, confirming the argument of Pálné Kovács et al (2004) that 'top-down' regionalisation (in the Hungarian context) has not fundamentally changed the territorial division of power.

In practice, the participation of regional institutions varies considerably between the EU8, as institutional legacies and domestic policy preferences have shaped the responses of domestic policy actors and institutions. In countries with weak or nonexistent regional administrative structures, centralised sectoral policy making was adopted as a more robust platform from which to develop and deliver EU programmes. Complicating the situation further, where the EU did exert an influence it was not necessarily consistent. In the member states where an early commitment was made to regional Structural Funds programmes for the 2004-06 period, guidance from the European Commission led to the abandonment of those plans, in favour of joint programmes. As Hughes et al (2004) note, in this respect, the position of the EU and its guidelines have been unclear and even inconsistent.

Taking into account the 'technical detail' of the Structural Funds also raises important questions about the current scope of regional participation in the development and delivery of the funds. As indicated earlier, in the EU8 member states regional Structural Funds programmes are only one aspect of the support provided. Explicitly 'regional' interventions make up a small proportion of the resources.

Second, this paper's detailed assessment of each stage of the Structural Funds implementation process reveals numerous limitations to regional participation. In many member states government ministries dominate the planning stages of the Structural Funds programming cycle. The capacity of regional institutions to feed effectively into programme planning has been doubtful, compounded by a lack of capacity at the regional level and a lack of commitment to enabling regional input at 
national level. Additionally, commitment to regional participation in principle is not necessarily followed through in practice.

Once the programmes were agreed, regions could take on an important role in managing programmes or element of the programmes. However, regional institutions have hitherto only been involved in the management of a limited number of programmes and interventions. The extent to which regions will have a substantial role in the future is still open for debate, with some regions expressing doubts over their ability to cope with the volume of work involved. Even in countries with comparatively well-established regions, the administration of highly complex EU funds could easily overload regional administrations, undermining what authority they have. Because of the complexity and administrative burden involved in the Structural Funds, there could be 'voluntary exclusion' on the part of the regions. At the very least, there is a 'capacity issue'.

In comparison to their involvement in the management of EU programmes, the involvement of regions in the implementation of the programmes is stronger. However, state agencies still play a dominant role, often at the expense of regional institutions. As previously noted, it is as final beneficiaries of the funds that subnational institutions have had their greatest involvement. Even in this case, there are caveats. Very often it is municipal authorities, as opposed to regional institutions, that are most actively involved in applying for funding. Also, the quality and quantity of the projects vary considerably across countries and regions. A further obstacle to regional participation is a perceived lack of funds to cofinance projects.

Third, and perhaps controversially, it can be argued that there is a conflict between regionalisation and effective Structural Funds management. This is the thesis of Pálné Kovács (2005) who regards the implementation of Structural Funds in Hungary as a "shock to the "regionalists" given that successful implementation of the funds depends less on directly regional government than professional management. Marinov et al (2006) elaborate on this argument (page 6): "decentralization and capacity building to absorb post-accession funding need not go hand-in-hand ... centralized structural fund programming and management may be needed to ensure the effective implementation of priority programmes." The massive increase of Cohesion policy funding for the EU8 member states agreed for the 2007-13 period is requiring huge investment in institutional capacity to ensure efficient and effective management, with the priority being to ensure sound financial management and control. In these circumstances, regionalisation may continue to be limited to the regional development OPs or to specific priorities and measures.

These points challenge the notion that Structural Funds lead to 'stronger regions' and build regional structures and competence. Instead, the paper argues that there is no guarantee that the Structural Funds will necessarily promote the role of regional authorities or regionalisation. Looking to the future, as Baun and Marek (2006) note with reference to the Czech case, there is the possibility for greater regionalisation. However, they go on to point out that a key determinant of the influence of regions will be the ability of the regional governments to "wrest greater control in the management and use of EU Structural Funds from the central government" (Baun and Marek, 2006, page 425). So far, EU Structural Funds have not automatically ensured a strong role for regions and regionally based development initiatives. However, in a situation of scarce domestic funding for regional policy interventions, weak regional institutional capacity, and limited financial resources, decisions on the future direction, content, and frameworks for Structural Funds could have a substantial impact, by either reinforcing centrally controlled policy making or supporting regional engagement in development initiatives. Alternatively, if few changes are made to the current arrangements, 
an extremely mixed, and at times confused, picture of regional participation in Structural Funds is likely to persist.

Acknowledgements. The authors would like to thank colleagues at the European Policies Research Centre who contributed to the interview programme in the EU8 over the period 2003-05: Dr Sara Davies, Dr Martin Ferry, Tobias Gross, Richard Harding, Carlos Méndez, Dr Vít Novotny, Nina Quiogue and Professor Douglas Yuill. The authors are also grateful for the helpful comments provided by two anonymous referees on an earlier draft of this paper.

\section{References}

Amin A, 1999, "An institutionalist perspective on regional economic development" International Journal of Urban and Regional Research 23365 - 378

Bache I, 1999, "The extended gatekeeper: central government and the implementation of EC regional policy in the UK" Journal of European Public Policy $628-45$

Bachtler J, 2001, "Where is regional policy going? Changing concepts of regional policy", EPRC discussion paper, University of Strathclyde, http://www.eprc.strath.ac.uk/eorpa/reports2.cfm

Bachtler J, Downes R, 1999, "Regional policy in the transition countries: a comparative assessment" European Planning Studies $7793-807$

Bachtler J, Downes R, Gorzelak G, 2000, "Transition, cohesion and regional policy in Central and Eastern Europe: conclusions", in Transition, Cohesion and Regional Policy in Central and Eastern Europe Eds J Bachtler, R Downes, G Gorzelak (Ashgate, Aldershot, Hants) pp $355-378$

Bafoil F, 2002 Final report of ex ante evaluation of documents submitted on the account of Structural Funds Twinning PL 2001/IB/OT-O4 between Poland (Ministry of Economy) and France (DATAR) "Strengthening coordination and management capacities for Structural Funds" Phare, http://www.funduszestrukturalne.gov.pl/English/Evaluation/Evaluation+documents/

Bailey D J, 2006, "Governance or the crisis of governmentality? Applying critical state theory at the European level" Journal of European Public Policy 13 16-33

Bailey D, De Propris L, 2002, "EU structural funds, regional capabilities and enlargement", paper presented at the Regional Studies Association International Conference on Evaluation of EU Regional Policy: New Questions and New Challenges, Aix-en-Provence, 30 May-1 June

Barker D, 2005, "Decentralised programming = decentralised implementation?", paper presented to the Open Days Conference, Brussels, 12 October, http://ec.europa.eu/regional_policy/ opendays/CD/doc/d03.ppt

Baun M, 2002, "EU regional policy and the candidate states: Poland and the Czech Republic" European Integration $24261-280$

Baun M, Marek D, 2006, "Regional policy and decentralisation in the Czech Republic" Regional and Federal Studies $16409-428$

Benz A, Eberlein B, 1999, "The europeanisation of regional policies: patterns of multi-level governance" The Journal of European Public Policy 6329 - 348

Blažek J, 1999, "Local and regional development and policy in the Czech Republic in the 1990s", in Regional Policy Goes East: Essays on Trends and Lessons Learned for Regional Development Policy in Central and Eastern Europe Eds V Hudak, H Huitfeldt, E Meegan (Institute for East West Studies, Prague) pp 44-65

Blažek J, Vozáb J, 2006, "Ex-ante evaluation in the new member states: the case of the Czech Republic" Regional Studies $40237-248$

Blažek J, Přikryl J, Nejdl T, 2003, “The Czech Republic”, in Investing in Regional Development: Policies and Practices in EU Candidate Countries Ed. K Davey (Open Society Institute, Budapest) pp $15-45$

Blom-Hansen J, 2005, "Principals, agents and the implementation of EU cohesion policy” Journal of European Public Policy $12624-648$

Börzel T, 1999, "Towards convergence in Europe? Institutional adaptation and Europeanisation in Germany and Spain" Journal of Common Market Studies 37573 - 596

Brusis M (Ed.), 1999, "Regional policy-making in Bulgaria, the Czech Republic, Estonia, Hungary, Poland and Slovakia", CAP working paper, Munich

Brusis M, 2005, "The instrumental use of European Union conditionality: regionalization in the Czech Republic and Slovakia” East European Politics and Societies 19291 - 316 
Council of the European Union, 2006, "Council Regulation (EC) No 1083/2006 laying down general provisions on the European Regional Development Fund, the European Social Fund and the Cohesion Fund and repealing Regulation (EC) No 1260/1999" Official Journal of the European Union 31 July, L210/25

Coyle C, 1997, "European integration: a lifeline for Irish local authorities?", in European Integration and Local Government Eds M Goldsmith, K Klausen (Edward Elgar, Cheltenham, Glos) pp $75-94$

Cumbers A, 2000, "The national state as mediator of regional development outcomes in a global era: a comparative analysis from the UK and Norway" European Urban and Regional Studies 7 $237-252$

Davies S, Gross T, 2005, “The challenges of designing cohesion policy strategies”, paper presented at Benchmarking Regional Policy in Europe: Second International Conference, Riga, 24-26 April

ECORYS, 2003 Regionální Akční Plán-Moravskoslezsko [Regional Action Plan-Moravia-Silesia Region], Ministry for Regional Development, Prague

ECR, 2004 Finalising Structures and Measures to Increase the Absorption Capacity at National and Regional Levels European Commission Representation in the Czech Republic, Prague

EMoF, 2003 Estonian National Development Plan for the Implementation of the EU Structural Funds, Single Programming Document 2004-2006 Estonian Ministry of Finance, Tallinn

European Commission, 2001, Directorate General for Regional Policy Chapter 21 Regional Policy and Coordination of Structural Instruments DG Enlargement, Brussels, http://europa.eu.int/ comm/enlargement/negotiations/chapters/chap21/index.htm

European Commission, 2004, "Structural Fund strategies for the new member states: $€ 24$ billion to ensure growth and cohesion between 2004-2006", press release, MEMO/04/156, 23 June, http://europa.eu/rapid/

European Commission, 2005 The Impact and Added Value of Cohesion Policy DG REGIO, Commission of the European Communities, Brussels

European Commission, 2006 The Structural Funds in 2004: Sixteenth Annual Report (Office for Official Publications of the European Communities, Luxembourg)

Fabbrini S, Brunazzo M, 2003, "Federalizing Italy: the convergent effects of europeanisation and domestic mobilisation" Regional and Federal Studies 13100 - 120

Ferry M, 2003a, "The EU and recent regional reform in Poland" Europe - Asia Studies 551097 - 1116

Ferry M, 2003b, "Regional governance in the EU: a comparative assessment", paper prepared for the twenty-fourth meeting of the EPRC Regional Policy Research Consortium, Ross Priory, Loch Lomondside, 6-7 October, http://www.eprc.strath.ac.uk/eorpa/reports2.cfm

Ferry M, 2007, "From government to governance: Polish RDAs in a changing regional context" East European Politics and Societies forthcoming

Ferry M, McMaster I, 2003, "Implications of EU regional assistance programmes in MoraviaSilesia and Upper Silesia", in EU Accession, Regional Policy, Social and Economic Development in East Central Europe Eds S Smith, M Myant, European Studies occasional paper (new series), PBS Working Paper Series No. 2003/03, University of Paisley, Paisley

Ferry M, McMaster I, 2005, "Implementing Structural Funds in Polish and Czech Regions: convergence, variation, empowerment?” Regional and Federal Studies 1519 - 39

Fowler B, 2001, "Debating sub-state reform on Hungary's 'road to Europe'", ESRC WP 21/01, http://www.one-europe.ac.uk/pdf/wp21.pdf

Gorzelak G, 1996 The Regional Dimension of Transformation in Central Europe (Jessika Kingsley, London)

Gorzelak G, 2004, "Polish regional development in the process of European integration", in Readiness of the Candidate Countries for the EU Regional Policy Ed.V Benc (Slovak Foreign Policy Association, Bratislava) pp 199-205

Grabbe H, 2003, "Europeanisation goes East: power and uncertainty in the EU accession process", in The Politics of Europeanisation Eds K Featherstone, C Radaelli (Oxford University Press, Oxford) pp $303-327$

Grosse T G, 2004, "The status of regional administration preparations for the absorption of EU structural assistance" Analyses and Opinions number 18, The Institute of Public Affairs, Warsaw

Habuda J, 2004, "Macroeconomic impacts of the Hungarian National Development Plan for 2004 -2006", in Readiness of the Candidate Countries for the EU Regional Policy Ed.V Benc (Slovak Foreign Policy Association, Bratislava) pp 57-64

Halkier H, 2006 Institutions, Discourse and Regional Development: The Scottish Development Agency and the Politics of Regional Policy (Peter Lang, Brussels) 
Heinelt H, Smith R (Eds), 1996 Policy Networks and European Structural Funds (Avebury, Aldershot, Hants)

Hooghe L (Ed.), 1996 Cohesion Policy and European Integration: Building Multi-level Governance (Oxford University Press, Oxford)

Hooghe L, Marks G, 2001 Multi-level Governance and European Integration (Rowman and Littlefield, Boulder, CO)

Horvath A, Maier G, 2004, "Regional development, absorption problems and the EU Structural Funds: some aspects regarding administrative absorption capacity in the Czech Republic, Estonia, Hungary, Slovakia and Slovenia", paper presented to the 44th European Congress of the European Regional Science Association 'Regions and Fiscal Federalism', University of Porto, August, http://www.ersa.org/ersaconfs/ersa04/PDF/951.pdf

Hübner D, 2006, "Delivering Lisbon through cohesion policy", speech to the Conference, "Making Partnership Work - Regional and Local Authorities for Growth and Jobs", 1 March (Committee of the Regions, Brussels)

Hudson R, 1997, "Regional futures: industrial restructuring, new high volume production concepts and spatial development strategies in the New Europe" Regional Studies $31467-478$

Hughes J, Sasse G, Gordon C, 2004, "Conditionality and compliance in the EU's eastward enlargement: regional policy and the reform of sub-national government" Journal of Common Market Studies 42523 - 551

Illner M, 2002, "Thirteen years of reforming subnational governments in the Czech Republic", paper presented at Conference on Reforming Local Government: Closing the Gap Between Democracy and Efficiency, 26-27 September, University of Stuttgart, http://www.uni-stuttgart.de/soz/avps/rlg/papers/CZ-IIlner.pdf

Johansson M, 1997, "Implementation of the Objective 6 Programme in Finland and Sweden", in The Coherence of EU Regional Policy: Contrasting Perspectives on the Structural Funds Eds J Bachtler, I Turok (Jessica Kingsley, London) pp 186-301

Jones M, 2001, "The rise of the regional state in economic governance: 'partnership for prosperity' or new scales of state power?" Environment and Planning A 33 1185-1211

Kálmán J, 2002, "Possible Structural Fund absorption problems", in Regionalisation for Development and Accession to the European Union: A Comparative Perspective Ed. G Marcou (The Open Society Institute, Budapest) pp $29-63$

Keating M, 1995, "Europeanism and regionalism in the European Union and the Regions", in The European Union and the Regions Eds B Jones, M Keating (Clarendon Press, Oxford) pp 1-22

Keating M, 2003, "Regionalisation in Central and Eastern Europe", in The Regional Challenge in Central and Eastern Europe: Territorial Restructuring and European Integration Eds M Keating, J Hughes (Peter Lang, Oxford) pp 51-68

Kelleher J, Batterbury S, Stern E, 1999 The Thematic Evaluation of the Partnership Principle in the EU Structural Fund Programmes 1994-1999: Final Report (Commission of the European Communities, Brussels)

Kleyn W H, Bekker M, 1997, "Integrated regional development under EU regional policy: the Dutch experience", in The Coherence of EU Regional Policy: Contrasting Perspectives on the Structural Fund Eds J Bachtler, I Turok (Jessica Kingsley, London) pp 260 - 273

Kondor Z, 2004, "Implementing Structural Funds in Hungary", paper presented at Open Days 2004 Conference on Cohesion Policy, Brussels, 27 - 30 September, http://ec.europa.eu/ regional_policy/opendays/0d2004/ppt/RG05\%20Kondor.ppt

Laffan B, 2004, "Multi-level governance: the dynamics of EU cohesion policy: a comparative analysis", OEUE Phase II occasional paper, 3 -9 April, Dublin European Institute University College, Dublin

LMoF, 2003 Single Programming Document for the Latvia Objective 1 Programme 2004-2006 Latvian Ministry of Finance, Riga

Lovering J, 1999, "Theory led by policy: the inadequacies of the 'new regionalism' (illustrated from the case of Wales)" International Journal of Urban and Regional Research 23379 - 390

McClements C, Smolkova H, 2004 Final Report of the ABCAP Project (ABCAP: Finalising of Structures and Measures to Increase the Absorption Capacity and National and Regional Level), Ministry for Regional Development, Prague

McMaster I, 2006, "Czech regional development agencies in a shifting institutional and policy landscape" Europe - Asia Studies $58347-370$ 
McMaster I, Bachtler J, 2004, "Ex-ante analysis of the influence of structural pre-accession aid and the structural funds on balanced territorial development", EPRC component of ESPON 2.2.2. 'Pre-accession Aid' Work Package 6, http://www.espon.lu/online/documentation/projects/ policy_impact/policy_impact_77.html

McMaster I, Bachtler J, 2005, "Implementing Structural Funds in the new Member States: ten policy challenges", paper presented at Scottish Executive EU Conference as part of the European Week of Regions and Cities-Open Days 2005, 12 October, Brussels; copy available from authors

Marek D, Baun M, 2002, "The EU as a regional actor: the case of the Czech Republic" Journal of Common Market Studies 40895 - 919

Marinov V, Bahloul H, Slay B, 2006, "Structural Funds and the new member states: lessons learned" Development and Transition 4 5-7

Marks G, Nielsen F, Ray L, Salk J, 1996a, "Competencies, cracks and conflicts: regional mobilisation in the European Union", in Governance in the European Union Eds G Marks, F Scharpf, P Schmitter, W Streek (Sage, London) pp 40-63

Marks G, Hooghe L, Blank K, 1996b, "European integration from the 1980s: state-centric vs. multi-level governance" Journal of Common Market Studies 34341 - 378

Morgan K, 1997, "The learning region: institutions, innovation and regional renewal" Regional Studies $31491-504$

NEI, 2002 Assessing the Administrative Capacity Needed by the Candidate Countries to Effectively Manage the Structural Funds Final Report to the European Commission (DG REGIO/DG Enlargement), NEI Regional and Urban Development, ECORYS, Rotterdam

Ochojski A, 2003, "Entrepreneurial partnership in the local arena", paper presented at 2nd Scottish-Silesian Seminar, Regions in the Process of Change, University of Economics, Katowice, 21 May; copy available from the authors

Pálné Kovács I, 2004, "Challenges of regional policy and responses of traditional public administration in East-Central European countries" Society and Economy 26 325-339

Pálné Kovács I, 2005, "Shaping regional governance in Hungary", paper presented to Open Days Conference, Brussels, 11 October, http://ec.europa/eu/regional_policy/opendays/CD/doc/d22.doc

Pálné Kovács I, Paraskevolpoulos C J, Horváth G, 2004, "Institutional 'legacies' and the shaping of regional governance in Hungary" Regional and Federal Studies 14430 - 460

Roberts P, 2003, "Partnerships, programmes and the promotion of regional development: an evaluation of the operation of the Structural Funds regional programmes" Progress in Planning $591-69$

Slocock B, 2003, "EU assistance and CEE regional development", in EU Accession, Regional Policy, Social and Economic Development in East Central Europe Eds S Smith, M Mynant; PBS Working Paper Series, Centre for Contemporary European Studies, University of Paisley

Smith A, 1994, "Regional development and the restructuring of state socialism: a regulationist approach to the 'transition' in Slovakia”, Research Papers in Geography, University of Sussex, Brighton

Storper M, 1997 The Regional World: Territorial Development in a Global Economy (Guilford Press, New York)

Storper M, Scott A J, 1995, "The wealth of regions: market forces and policy imperatives in local and global context" Futures 27 505-526

Šumpíková M, Pavel J, Klazar S, 2004, "EU Funds: absorption capacity and effectiveness of their use, with focus on regional level in the Czech Republic", paper presented at 12th NISPAcee Annual Conference 'Central and Eastern European Countries Inside and Outside the European Union: Avoiding a New Divide', Vilnius, 13 - 15 May, http://unpan1.un.org/intradoc/groups/ public/documents/NISPAcee/UNPAN018547.pdf

Svensson B, Östhol A, 2001, "From Government to Governance: Regional Partnerships in Sweden" Regional and Federal Studies $1125-42$

Vilkas E, 2004, "Using EU Structural Funds and expected macro-economic impact on the Lithuanian economy", in Readiness of the Candidate Countries for the EU Regional Policy Ed.V Benc (Slovak Foreign Policy Association, Bratislava) pp 65-70

Yoder J, 2003, "Decentralisation and regionalisation after communism: administrative and territorial reform in Poland and the Czech Republic" Europe - Asia Studies 55263 -286 
This article is an advance online publication. It will not change in content under normal circumstances but will be given full volume, issue, and page numbers in the final PDF version, which will be made available shortly before production of the printed version.

Conditions of use. This article may be downloaded from the E\&P website for personal research by members of subscribing organisations. This PDF may not be placed on any website (or other online distribution system) without permission of the publisher. 